\title{
Cheap Talk or Proper Signaling? Styles of Campaigning and Engagement in
}

\author{
Constituency Service
}

\section{Mihail Chiru ${ }^{1}$}

\section{Objectives}

Although a salient component of parliamentary delegation and accountability chains, the connection between individual campaigning and parliamentary behaviour has not been measured systematically by empirical research. This study assesses the importance of campaign strategies and activities for constituency service.

\section{Methods}

We draw on an original dataset combining the responses of 234 MPs participating at the 2010 Hungarian Candidate Study with their subsequent parliamentary questions. We content-analyzed the questions and ran negative binomial regressions to evaluate if and how campaign activities influenced the MPs to introduce locally oriented questions.

\section{Results}

Our analyses show that a form of campaign socialization, the time devoted to meet local activists during campaigns, is a key predictor for the likelihood of introducing constituency questions, whereas campaign norms and messages matter less.

\section{Conclusions}

Ultimately even though campaigns matter for constituency service, the MPs' shadowing behavior, their socialization in local politics and their partisan affiliation is likely to matter more.

Date of acceptance: 20.06 .2016

\section{Acknowledgment}

The author acknowledges the support received from the Romanian Ministry of National Education, CNCS-UEFISCDI, through the project PN-II-ID-PCE-2012-4-0644: 'Re-thinking Individual Representation: Campaign Personalization and Legislative Behaviour (2013-16)' and by the UCLouvain through the 'MOVE-IN Louvain' Incoming Post-doctoral Fellowship, co-funded by the Marie Curie Actions of the European Commission. The author is grateful to Zsolt Enyedi, Gabor Toka and the two anonymous reviewers of the journal for their comments and suggestions on earlier versions of this article.

\footnotetext{
${ }^{1}$ Oxford School of Global and Area Studies, University of Oxford. Email address: mihail.chiru@area.ox.ac.uk, phone: 07518407676; postal address: 11 Bevington Road, UK, OX2 6NB. All data and code is available on request for replication purposes.
} 
Although a salient component of the parliamentary delegation and accountability chains (Strøm 2000), the connection between individual campaigning and parliamentary behaviour has not been measured systematically by empirical political research. Previous 'individualized campaigning' studies have only documented the extent and modes of personalization (Zittel and Gschwend 2008; De Winter and Baudewyns 2015; Chiru 2015) and their influence on candidates' overall electoral success (Eder et al 2015; Engeli and Lutz 2012).

In an innovative study, Hennl and Zittel (2011) maintained that campaign patterns mediate the effects of electoral systems on individual representation. In other words, electoral systems offer varying incentives to personalize campaigns, which in turn 'contribute to greater individualism in legislative contexts' (Hennl and Zittel 2011: 2). Nevertheless, the authors did not test their hypothesis on legislative behavior data but on MPs' self-declared foci of representation.

The present study is the first to match data on legislative responsiveness towards local interests with information on the campaign strategies and activities the MPs had engaged in as candidates. Since one of the most frequent contents of campaign personalization is represented by promises related to issues on the local agenda and self-depictions as the best equipped candidate to advance local interests, the study investigates the impact of this type of political communication on constituency service. However, the article shows that the socialization taking place during campaigns is better a predictor of constituency service than constituency-oriented political communication.

Thus, the central research question of the study asks: 'how much do campaign communication and socialization influence engagement in constituency service in a mixed electoral system?' The latter contextual element is chosen in order to better isolate the impact of varying electoral incentives for the campaign-behavior connection, while holding constant other factors that would 
affect a cross-systems design. The 'background' selected is the Hungarian Mixed-MemberMajoritarian (MMM) system: I combine data from the 2010 Hungarian Candidate Study with parliamentary questions data from the subsequent first two and a half years of mandate.

The introduction is followed by a review of the relevant scholarship, the main arguments and hypotheses of the research. The third section presents the research design: the case selection, data and the methods used. Next, I discuss the findings of the content analysis of parliamentary questions and interpellations. This is followed by the presentation of multivariate analyses and by further analyses of the main effects based on simulations. The conclusion synthesizes the main findings and their implications for the legislative behavior literature.

\section{Theoretical framework}

Much of the scholarship on parliamentary questions, starting with the influential volume edited by Wiberg (1994), assumed that they are primarily 'a mechanism for holding the executive branch accountable' (Martin 2011a: 262) by exploring 'individual and collective ministerial responsibility' (Blidook and Kerby 2011: 328) while having 'little application to cultivating relationships with constituents' (Martin 2011a: 262). The latter aspect has been researched only recently and mostly in electoral systems that do not lead to different channels of election (Soroka et al 2009; Blidook and Kerby 2011; Russo 2011; Martin 2011b; for a partial exception see: Bailer 2011).

Similarly, the constituency service literature has mostly ignored the actions and promises made by candidates and MPs in electoral campaigns, despite the fact that it is extremely intuitive to think that personal vote earning efforts (Carey and Shugart 1995) start originally at the campaign 
level. At best, these theories have seen the campaign as the moment when incumbents advertise efforts already made on behalf of their constituents (Mayhew 1974).

A third category of studies analyzed how electoral systems shape both campaigning and legislative behavior (Hazan 2001; Mayorga 2001; Crisp 2007; Rich 2013). A fair share of this literature concentrated on the debate regarding the specialization versus contamination (Ferrara et al 2005) of roles and activities of MPs elected in different electoral tiers of mixed electoral systems. Whereas the findings of studies analyzing the voting loyalty of MPs elected from different tiers remain inconclusive (Rich 2014), other studies have shown that in mixed electoral systems the type of seat influences the MPs' campaign style, and later on their behavior in the Parliament (Rich 2013). However, these studies did not make the additional step: measuring directly the connection between campaign communication and socialization and legislative behavior.

I argue that the amount of time and energy put into campaigning on local issues, meeting local party activists and campaign personalization will lead to a similar level of engagement in constituency service. One reason for this is that the MPs who had put a lot of effort into this type of campaigning would most likely perceive their electoral victory as a mandate for local interest representation. Also, having invested time in creating a personal reputation, distinct from the party, these MPs will want to maintain and develop it as a valuable asset in the quest for future votes and offices. Therefore, their parliamentary work agenda will include contacts with, and work on behalf of party activists and constituents. Beyond such rational calculations, a successful campaign focused on local agenda and local party networks could also play a socialization role, especially for newcomer MPs. For them, acting on the demands and needs of constituents and local party activists will be seen as the appropriate thing to do, the dimension 
that gives meaning to the job of representative beyond being a cog in the machine of party (collective) representation.

Some scholars regard with skepticism causal arguments explaining constituency service through campaign experiences and activities, and believe instead that both are just dimensions of the same latent variable, constituency orientation. If this skeptical perspective is right than the campaign-related variables should become insignificant once we control for the traditional determinants of constituency orientation such as experience in local politics.

Irrespective if one embraces a causal or a correlational perspective of the phenomenon, the linkage between individual campaigning and legislative behavior cannot be just assumed and needs to be tested empirically. Such a test is made necessary by two relatively strong counterexpectations, both having damaging consequences on individual representation from a normative point of view. First, there is the usual case for politicians, which also affects heavily programmatic linkages: not acting upon or delivering on what was promised. The second case, which can be equally problematic, would imply acting 'on behalf of constituents' without having requested a mandate for it. In this scenario what appears to be constituency service might at times amount to responsiveness to business interests in the constituency which could actually prove detrimental to the constituents themselves. After having introduced these counterexpectations the next paragraphs will discuss in detail the modes and mechanisms through which campaign strategies and activities can influence constituency service engagement.

Time is generally a scarce resource for politicians, but this should be even more the case during electoral campaigns. Decisions to organize certain events and not others and to meet certain people and not others speak simultaneously about two crucial aspects. First, they reveal the candidate's ideas about how she will win the necessary votes to get elected and where these 
votes are most likely to come from. Second, these decisions speak about which issues the future MP would consider as priorities in her representation work. When a candidate chooses to spend considerable time meeting local party members and activists, it can be assumed that both sides can turn to each other later on during the parliamentary term. The party members and activists could ask the MP whom they helped to get elected to advance their interests in various ways, from putting local problems on the national agenda to mediating interactions with central authorities. At the same time, these activists could be an invaluable source of information about policies or political processes that go wrong at local level, and have a potential to embarrass the government. Moreover, candidates that need to invest a lot of time into meeting party activists might also be in a rather weak position in relation to the local party organization. Promoting local issues into Parliament and running other errands could be used in this case by the MPs as means of consolidating this relation. Beyond these rational calculations, the time spent with local party activists is also an intense socialization experience, that can create bonds and make MPs more responsive to local issues and requests.

\section{H.1.: The more time devoted to meeting local party activists during the campaign, the higher the} number of constituency service questions raised by the MP.

One of the main areas of interest in the burgeoning literature on campaign individualization is the overall campaign norm, measuring how personalized as opposed to party-centered was the strategy chosen by the candidate. ${ }^{2}$ The attributes the candidates decide to emphasize when shifting campaign focus from the party to themselves vary heavily. However, one of the usual suspects, along with leadership skills and other political or personal qualities, is their ability to

\footnotetext{
${ }^{2}$ This is measured with the question: 'What was the primary aim of your campaign?'. The candidates had to respond using a $0-10$ scale in which the end points were labeled 'To attract as much attention as possible for my party' and 'To attract as much attention as possible for me as a candidate'.
} 
cater for the constituency (Hennl and Zittel 2011). Being a local or having ties with the constituency is another frequent type of content used to personalize the campaign message (Shugart et al 2005; Evans 2014), particularly since voters love local candidates (Campbell and Cowley 2014). The candidates for whom campaign individualization meant primarily presenting themselves as the 'right person' for representing territorial interests, might feel that their election amounts to a direct mandate for casework. On the long term, following the campaign promises and engaging in non-legislative district oriented activities could turn out to be a safety net for reelection, divorced from party fortunes.

H.2: The more individualized her campaign, the higher the number of constituency service questions raised by the MP.

With the potential exception of party leaders' effects there seems to be little evidence for a personal vote in Hungary (Enyedi and Tóka 2007). However, rather than limiting themselves to simply adhere to their party's national policy manifesto, a large number of parliamentary candidates promise solutions to local problems during campaigns (Chiru 2015). Of course, politicians who have been nominated in electorally safe districts or those who had built a reputation of policy experts may not feel the same pressure. Once in office, the candidates promoting a local agenda can nevertheless be expected to engage more in advocating the problems of their constituency given the increased media coverage of parliamentary activities ${ }^{3}$. Beyond the re-election drive that motivates a constant transformation of issues from the local campaign agenda into parliamentary initiatives and documents, localized campaigning should also foster constituency questions because it is a proxy for the MP's awareness of local problems.

\footnotetext{
${ }^{3}$ Two news portals cover extensively the MPs' parliamentary questions and interpellations: www.gondola.hu and www.hvg.hu. They are also presented on the national and county branches' party websites and on the MPs' weblogs and social media accounts.
} 
H.3: Candidates who had promoted a local agenda during the campaign will ask as MPs a higher number of constituency service questions.

These three hypotheses form the core theoretical argument for which campaigns should matter for engagement in constituency service. Additionally, the analysis considers six control variables that have been emphasized by the scholarship on constituency service determinants. The first two refer to the electoral system incentives and the psychological consequences derived from them.

The type of seat the candidate wins in electoral systems with multiple tiers of election ${ }^{4}$ has attached to it a series of normative expectations from voters, party leaders and fellow parliamentarians about the appropriate legislative and non-legislative behavior associated with that mandate. On the one hand, MPs who won single member districts are expected to look after their voters and try to maintain and increase their support, particularly through constituency service. On the other hand, the overriding expectation towards list parliamentarians is that they specialize in particular policy areas, while being allowed the privilege of not engaging in casework. Beyond these normative expectations, the same type of specialization should also be fostered by the parliamentarians' strategic understanding of their re-election prospects provided by the electoral system. In the Hungarian case, scholars were successful in documenting the linkage between the MPs' channels of election and attitudinal differences with respect to representation roles (Judge and Ilonszki 1995; Papp 2011; Enyedi 2011; Chiru and Enyedi 2015) but evidence about differences in actual behavior remains scarce (for the exception see: Montgomery 1999). Because of these aspects I expect directly elected MPs to ask a higher number of constituency service questions than list parliamentarians.

\footnotetext{
${ }^{4}$ The Hungarian Parliament was elected until the 2012 electoral reform through a mixed-member majoritarian (MMM) electoral formula. According to this formula 176 MPs were elected in SMDs, a maximum of 152 were elected in MMDs (county lists) and at least 58 through a national, 'compensatory list', that aggregated the surplus votes and distributed also any seats not allocated in the county tier (Benoit 2001).
} 
Nevertheless, the Hungarian electoral system also presented a great potential for contamination because of the large number of candidates that run simultaneously in the nominal and the list tiers (Benoit 2001; Papp 2011; Chiru 2015). Given this context, the logic of candidacy could trump the 'seat logic' and the aforementioned expectations vis-à-vis the mandate. The legislative studies literature has theorized and illustrated empirically instances of 'shadowing behavior': list MPs that engage in constituency service in the single member electoral district they lost (Lundberg 2006; Norris 2004). The explanations offered for this behavior include the desire of such MPs to win the direct seat at the next elections, the need to maintain and cultivate local electorates as well as the demand factor (Papp 2011). Thus, strongly partisan citizens would prefer to approach an MP of their preferred party who does not represent the district rather than turn to their 'official' representative from another party (Lundberg 2006). Shadowing was already documented for Hungarian list MPs in the first post-communist decade, precisely with respect to interpellations on local issues (Montgomery 1999: 514). Therefore, I expect list MPs who have lost SMD battles to raise more constituency-related questions than the rest of their colleagues.

Generally, incumbents and veteran MPs are expected to be less concerned by their re-election and therefore less interested in casework than newcomers for two reasons. First, because they can, hypothetically, rely on a reservoir of voter goodwill due to a record of service and pork directed in the past to the constituency (Heithshusen et al. 2005: 37). Second, because it is likely that they have built the necessary intra-party relations to ensure an advantageous re-nomination. In Hungary it seems that parties systematically choose to secure the election of their high-level cadres by nominating them to eligible positions at all three levels (Benoit 2001). 
Another factor that needs to be controlled for is political experience at local level. MPs who acted as mayors or local councilors are in a better position to engage in casework and constituency service in general because they are knowledgeable of the region's specific problems and connections with local authorities and voters are already in place (Freeman and Richardson 1996). At the same time, scholars speak about a socialization effect because experience in local government appears to also foster a particular understanding of the representation role which subsequently with the election in Parliament, just transfers to the national level (Norris 1997: 3334). Moreover, the relationship was also corroborated by a case study that used constituencytargeted parliamentary questions as the main indicator for service (Russo 2011: 296-299).

I also control for the MPs' ideological distance from their party. The expectation is that the MPs who see themselves further away from the median member of the party on the left-right scale are more likely to devote time to policy issues than to running errands for their constituents.

\section{Research design}

Attempting to document the relation between campaign personalization and individual representation in Hungary does not amount to 'a least likely design' but is nevertheless particularly challenging. Despite evidence regarding significant individualization of political communication during campaigns (Chiru 2015) and the incentives provided by the dominant SMD component of the mixed electoral system, legislative behavior appears highly partydominated. Not only is voting dissent extremely rare (Ilonszki 2000) but also previous empirical studies have failed to find any evidence that the electoral incentives associated with the different type of seats have any influence with respect to breaking the party line at roll call votes (Ishiyama 2000: 890-892; Thames 2005: 296). 
Moreover, the initiation of private member bills is controlled to some extent by the parliamentary party group leadership and even the usage of parliamentary questions and interpellations - which is the least controlled activity in most parliaments (Martin 2011a) - has been partially orchestrated for party objectives. This refers mainly to the practice of majority MPs to table questions and interpellations that do not attempt to scrutinize but to advertise governmental policies (Ilonszki 2007: 54). Nevertheless, by comparing the degree of control exercised by party leaders on parliamentary votes and questions, it becomes immediately evident that it is more appropriate to measure constituency orientation by analyzing the content of parliamentary questions than by looking at roll-call behavior.

Most of the MP data comes from the Hungarian Candidate Study (Enyedi 2010) which was conducted four months after the April 2010 general elections. A number of 432 politicians responded, out of which 241 were elected candidates. Only the responses of $234 \mathrm{MPs}^{5}$ were used in the analyses, because 7 of them could not be identified.

Direct questions were introduced in the Hungarian Parliament as a form of executive scrutiny by the 1994 standing orders (Ilonszki 2007: 53). According to the Standing Orders MPs have four types of parliamentary questions at their disposal: interpellations, oral questions, written questions and spontaneous questions ${ }^{6}$. Interpellations are the most powerful because of the follow-up they require: 'if the MP does not accept the answer he was given, the National Assembly takes a vote, and if this vote is negative, the issue raised in the interpellation comes back to the plenary in the form of a report submitted by the investigating committee'.

The parliamentary questions and interpellations were collected from the official website of the Parliament. In deciding whether a question or interpellation could be considered a constituency

\footnotetext{
${ }^{5}$ This figure represents $60.6 \%$ of all parliamentarians. The sample is highly representative with respect to party affiliation.

${ }^{6}$ This study analyzes questions and interpellations belonging to all categories but the written ones. I took this decision because the written questions are the least covered by the media and thus the least likely to be noticed by constituents.
} 
service act I applied the framework for coding localism developed by the Comparative Policy Agendas Project (Baumgartner et al. 2006) and adapted by Martin (2011a).

The independent variables' operationalization is relatively straightforward, being presented in detail in the online appendix ${ }^{7}$. The only variable in need of additional explanations is the ideological distance. This uses the absolute difference between the MP's self-placement on the 010 left-right scale and the party's perceived ideological position on the same scale. The latter is the mean of the party placement scores assigned by all the candidates of the respective party.

I use negative binomial regressions to test the hypotheses. This was the most appropriate method for modeling given the nature of the dependent variable - count data and because of its overdispersion. Moreover, I use incidence rate ratios, run margins and make simulations with Clarify (King et al 2000) to facilitate the interpretation of the results.

\section{The content and partisan distribution of parliamentary questions}

The 234 Hungarian MPs in the sample have asked in the first two and a half years of mandate (May 2010 - December 2012) 871 parliamentary questions and made 414 interpellations. 58.1\% of these MPs never raised a constituency related issue, whereas almost one third (31.6\%) did not table any question or interpellation whatsoever.

After content-analyzing all of the 1285 questions and interpellations, it resulted that only 235 of them (18.3\%) can be considered constituency service acts. ${ }^{8}$ For a comparison, in Ireland - which has a much more candidate-centered electoral system Martin (2011b) found that $45 \%$ of the written parliamentary questions submitted between 1997 and 2002 addressed a constituency

\footnotetext{
${ }^{7}$ The online appendix can be reached at: http://bit.ly/28I19b4

${ }^{8} 12.3 \%$ of the service questions raised issues from other counties than the ones those MPs were elected from. In most of these cases, incumbent MPs inquired about things happening in the constituency they represented in the previous term. This implies that some ties are maintained despite changing the county or running only on the national list.
} 
issue, while in the Italian $15^{\text {th }}$ Legislature (2006-2008) elected under a closed list PR system Russo (2011) found that $39.3 \%$ of all parliamentary questions could be considered 'constituency oriented questions'. This comparative under-engagement in constituency service is a finding in itself and would deserve a separate analysis, which would have to account for the institutional differences, particularly the questioning procedures.

More than two thirds of the constituency service questions (68.1\%) were asked by opposition MPs. Actually, the MPs of the 'Movement for a Better Hungary' (JOBBIK) asked alone $40 \%$ of all questions and interpellations targeting a territorial issue. They are followed by the MPs of the ruling party, FIDESZ, with a share of $30.6 \%$, but the mean number of interventions of these MPs is the second last in the Parliament. The MPs of the Socialist Party (MSZP) tabled roughly one quarter $(25.5 \%)$ of the constituency-related questions. ${ }^{9}$

There is a moderate correlation: Pearson's $\mathrm{R}=.354^{* * *}$ between the number of policy questions and interpellations addressed by the Hungarian MPs and the number of constituency service questions. This implies that there is a limited specialization in asking parliamentary questions: the most active members engage in both policy-making activities and constituency service.

Figure 1 below presents the content and frequency of the constituency related questions raised by the Hungarian MPs, aggregated into 15 categories. More than one in five (20.8\%) asked about current developments regarding infrastructure investments in their counties: from cycle lanes to airports. The second most common topic (15.7\%) referred to local job creation, state aid for factories and local industries with problems.

\section{Figure 1 about here}

\footnotetext{
${ }^{9}$ The shares of the green party, 'Politics Can Be Different' (LMP) and the junior coalition partner, Christian Democratic People's Party (KDNP) amount to $2.5 \%$ and $1.2 \%$ respectively.
} 


\section{Campaign choices, logic of candidacy effects and the partisan dimension}

The analysis is carried out in two stages. In the first stage, I use negative binomial regressions to test the hypotheses. The second stage includes further analyses of the effects of the main independent variables that keep constant all other factors and a discriminant validity test: a replication of the multivariate models with policy questions as the dependent variable.

Table $1^{10}$ below presents the findings of the three negative binomial regression models estimating the number of questions and interpellations dealing with constituency issues. The cell entries in table 1 are incidence rate ratios.

The baseline model emphasizes the importance of campaign activities and strategies while also presenting a counterintuitive finding. First, a positive effect is associated with meeting local activists during the campaign. Second, one point increase on the scale of campaign individualization brings an increase in the rate of constituency service questions of $15 \%$. The model also corroborates the third hypothesis: MPs who promoted local issues in their campaigns seem to ask significantly more constituency questions. These results will be analyzed in more depth in the next section.

With respect to the control variables, a particular counterintuitive effect stands out. Thus, MPs elected from county and national lists seem to engage almost four times as much in the representation of geographically defined interests as those elected from single member districts (the baseline category). However, there is a peculiar mechanism at work behind this effect that the second model will reveal.

There seem to be no substantial differences in questioning patterns according to the number of parliamentary mandates. Also, incumbents are less eager to cultivate a personal vote: they ask

\footnotetext{
${ }^{10}$ In models not shown here, I have also controlled for the influence of self-declared foci of representation, level of nomination, district magnitude, local and regional party office, having a dual mandate (MP and mayor or MP and local councilor) and gender. None of these variables produced a substantial effect and I chose to present only the most parsimonious models.
} 
2.1 times fewer constituency questions than MPs who are elected for the first time or return to Parliament after a break of one or more terms.

\section{Table 1 about here}

Introducing three additional controls in the second model: a dummy for shadowing and variables measuring experience in local politics and the ideological distance from the party turns insignificant the campaign norm and the degree of campaign localization, although both still point in the hypothesized direction. This is not surprising given that the type of candidacy (especially the lowest tier in case of multiple candidacies) and experience in local politics are among the main predictors of campaign styles and contents in Hungary (Chiru 2015). On the contrary, meeting local activists during the campaign remains an important predictor of asking constituency questions, the magnitude of the effect being similar to that resulting from the first model. This is evidence that intense campaign socialization episodes can have lasting effects for legislative behavior, irrespective of candidates' background and electoral tiers of candidacy.

The second model also reveals the considerable effect of 'shadowing'. Thus, parliamentarians, who ran in SMDs and lost, initiate eight times more parliamentary questions and interpellations having a local dimension than the rest of their colleagues. This effect was actually driving the unusual finding in model 1: after controlling for 'shadowing' both categories of county and national list MPs appear less active with respect to territorial representation than SMD representatives. In the Hungarian context shadowing was at least partially a rational behavior: some MPs ${ }^{11}$ could hope that they will be able to win at the next elections the SMD they lost in 2010 due to an erosion in the FIDESZ vote.

\footnotetext{
${ }^{11}$ Particularly the Socialist Party (MSZP) MPs, which has been the governing party from 2002 until 2010.
} 
Socialization into local politics also appeared to be a significant predictor of constituency service engagement. Thus, if one would compare MPs who have never held a local political office with their counterparts who have had 10 years of such experience, the latter's rate of parliamentary questions over local issues would appear $20 \%$ higher.

The last control variable included in the second model, ideological distance, entails a negative effect on constituency service. The effect is small but significant: running margins showed that 1 point difference on the left-right scale decreases the number of parliamentary questions and interpellations dealing with local issues by 0.26 . One possible explanation could be that MPs less interested in policy and more in non-legislative aspects of representation tend to see themselves more ideologically congruent with their parties.

The last model accounts for the partisan differences in questioning patterns. It appears that JOBBIK MPs ask eight times more locally oriented questions than the FIDESZ parliamentarians, whereas LMP MPs seem 4.6 times more interested in constituency issues. Just four of the other variables display significant effects when introducing the party dummies: the frequency of meeting party activists during the campaign, incumbency, experience in local politics and ideological distance, all pointing in the expected directions. Unsurprisingly, the shadowing effect disappears when controlling for the partisan affiliation. This can be related straightforwardly with the fact that FIDESZ and KDNP won together 173 out of the 176 SMD mandates.

\section{Further interpretation of results and robustness checks}

To make the interpretation of the main finding more straightforward I used the STATA program Clarify (King et al 2000), with which I run simulations based on the third model. In this way I 
generated the expected values of the dependent variable against the values of the 'meeting local activists' variable, while keeping all other variables at their mean.

Thus, Figure 2 below plots the expected number of constituency questions with $95 \%$ confidence intervals against the frequency of meeting local activists during the campaign. It turns out that MPs who spent no time meeting local party activists during the campaign ask zero constituency questions, all other things being equal. At the other end of the scale, MPs who got involved the most in this activity raise on average around 1.2 constituency questions, all other things being equal.

\section{Figure 2 about here}

A counterargument to the connection between campaign activities and asking constituency service questions could be that hyperactive MPs who try to build a reputation could simply put more effort into their campaigns and then also maintain a very high level of engagement in various parliamentary activities. If this is true than we should also see a strong empirical link between the three campaign related variables and the number of policy questions asked by Hungarian MPs. Re-running the regressions in Table 1 with the number of policy questions as dependent variable showed that campaign decisions and campaign activities have no influence on asking policy questions.

\section{Conclusion}

The most significant contribution brought forward by this study is that it illustrates empirically for the first time the explanatory power of campaign socialization and activities for engagement 
in constituency service. This is done within the scope of a quasi - least likely design, in which individual behavior is highly controlled by parties.

The fact that one campaign activity - the frequency of meetings with local party activists remains a significant predictor for the number of constituency questions even after controlling for all other personal and institutional factors seems to suggest that in Hungary MPs are first and foremost responsive to their party branches on local issues and that their connection with the local party is probably one of the main channels for articulating local interests.

Another important finding is that the campaigning and electoral system variables emerged simultaneously as significant predictors of legislative behavior, which could mean that campaigns are more than just a mediating factor for the connection between the incentives created by the electoral formula and the representatives' actions.

Studies linking campaign and legislative arenas have the potential to improve our understanding of how individual accountability works. A desirable complementary line of research would be to content-analyze actual promises on local issues made during campaigns and then evaluate the degree in which they match the content of the MPs' constituency oriented parliamentary questions and bills. Future research could also move beyond the constituency linkage focus of this research and analyze whether campaign choices influence the MPs' roll-call voting behavior or their policy-making activities. 


\begin{tabular}{|c|c|c|c|}
\hline & Model 1 & Model 2 & Model 3 \\
\hline Meeting local activists & $1.475 * * *$ & $1.367 * * *$ & $1.362 * * *$ \\
\hline Campaign norm & $1.148 * * *$ & 1.029 & 1.055 \\
\hline Constituency agenda & $1.631 *$ & 1.103 & 1.179 \\
\hline County list MP & $3.837 * * *$ & 0.885 & 0.783 \\
\hline National list MP & $3.925 * * *$ & 0.717 & 0.617 \\
\hline Years in Parliament & 1.038 & $1.045^{*}$ & 1.039 \\
\hline Incumbent & $0.470 * *$ & $0.386^{* * *}$ & $0.561 *$ \\
\hline Shadowing MP & & $7.888 * * *$ & 1.804 \\
\hline Local politics experience & & $1.021 * *$ & $1.027 * * *$ \\
\hline Ideological distance & & $0.805 * *$ & $0.744 * * *$ \\
\hline KDNP & & & 0.719 \\
\hline MSZP & & & 3.161 \\
\hline JOBBIK & & & $8.157 * * *$ \\
\hline LMP & & & $4.657^{*}$ \\
\hline Lnalpha & -0.125 & -0.698 & -0.930 \\
\hline Alpha & $0.882 * * *$ & $0.497 * * *$ & $0.395 * * *$ \\
\hline Maximum Likelihood $\mathrm{R}^{2}$ & 0.242 & 0.352 & 0.386 \\
\hline Observations & 211 & 199 & 199 \\
\hline
\end{tabular}

* Significance at $* \mathrm{p}<0.10, * * \mathrm{p}<0.05, * * * \mathrm{p}<0.01$

$* *$ Cell entries are incident rate ratios.

12 Regression diagnostic tests showed that the models are not affected by multicollinearity - they display very small variance inflation factors. 


\section{Figure 1}

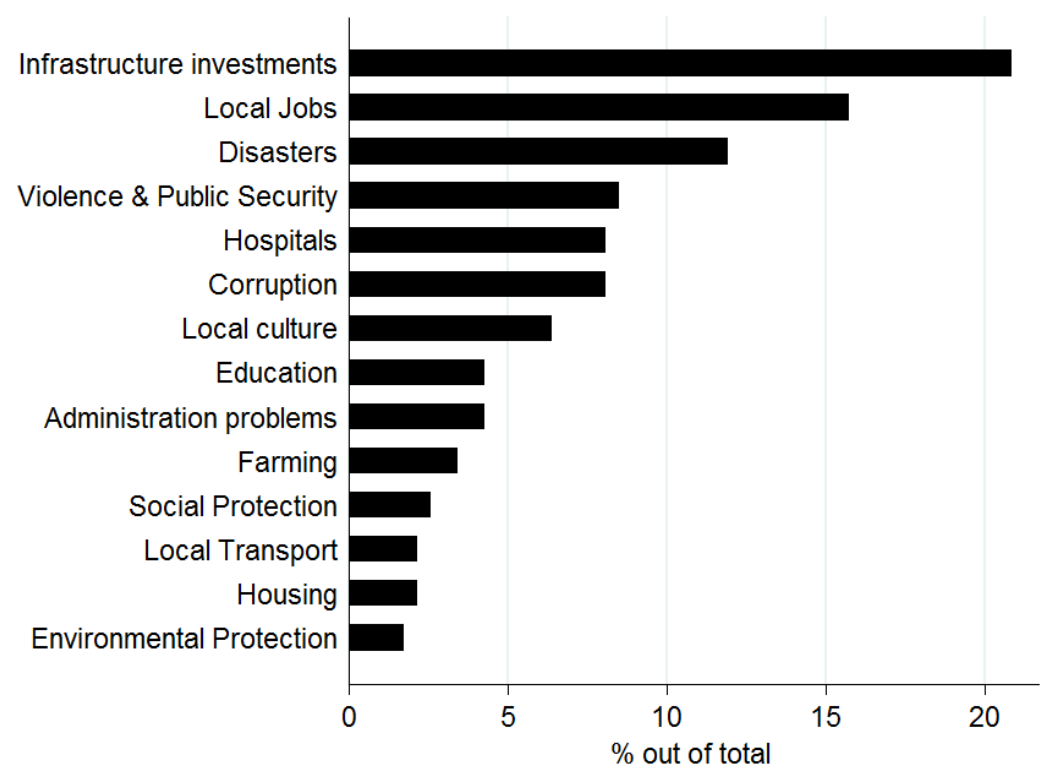

Figure 2

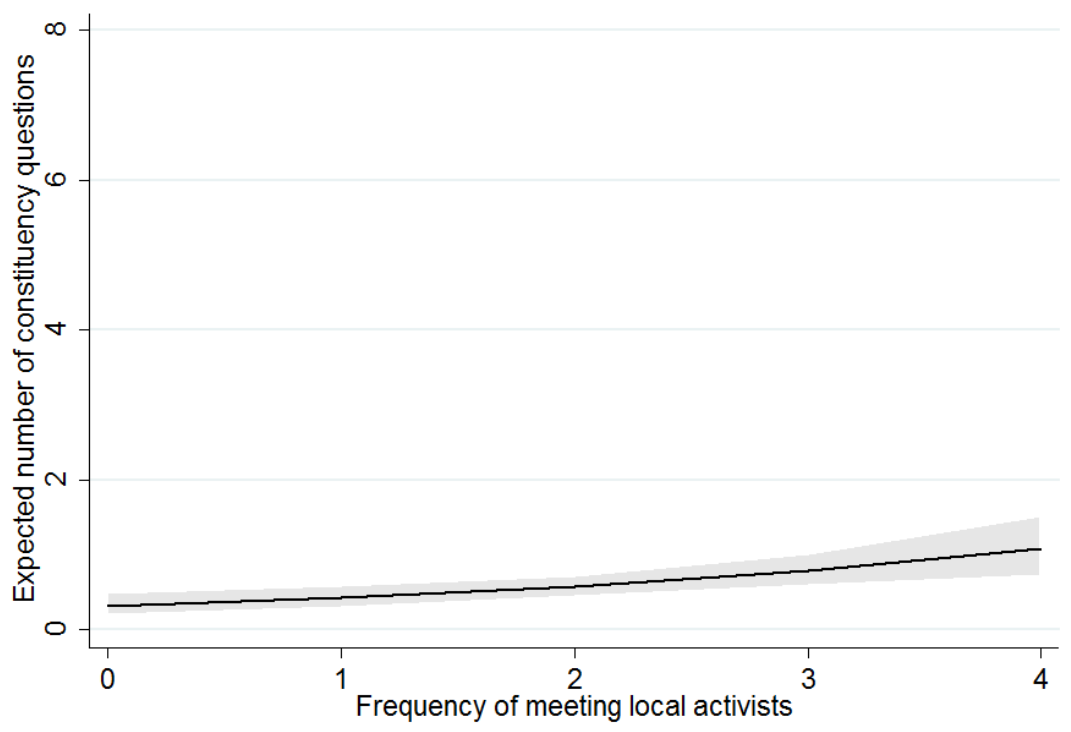

All other independent variables held at their mean 


\section{References}

Bailer, S. 2011. 'People's Voice or Information Pool? The Role of, and Reasons for, Parliamentary Questions in the Swiss Parliament', The Journal of Legislative Studies 17(3): 302-314.

Baumgartner, F.R., Green-Pedersen, C., and B.D. Jones. 2006. 'Comparative Studies of Policy Agendas', Journal of European Public Policy, 13(7): 955-970

Benoit, K. 2001. 'Evaluating Hungary's Mixed-Member Electoral System', in Shugart, M.S. and M. P. Wattenberg (eds.) Mixed-Member Electoral Systems: The Best of Both Worlds?, Oxford: OUP, pp. 477-93

Blidook, K. and M. Kerby. 2011. 'Constituency Influence on 'Constituency Members’: The Adaptability of Roles to Electoral Realities in the Canadian Case', The Journal of Legislative Studies 17(3): 327-339.

Campbell, R. and Cowley, P. 2014. 'What Voters Want: Reactions to Candidate Characteristics in a Survey Experiment', Political Studies, 62(4): 745-765

Carey, J. M., and M. S. Shugart. 1995. 'Incentives to Cultivate a Personal Vote: A Rank Ordering of Electoral Formulas', Electoral Studies, 14: 417-439.

Chiru, M. and Enyedi, Z. 2015.' Choosing your own boss: Variations of representation foci in mixed electoral systems', The Journal of Legislative Studies, 21(4): 495-514.

Chiru, M. 2015. 'Multiple Candidacies and the Role of the Lowest Electoral Tier for Individualized Campaigning', East European Politics and Societies 29(4): 892-914.

Crisp, B. F. 2007. 'Incentives in mixed-member electoral systems general election laws, candidate selection procedures, and cameral rules', Comparative Political Studies, 40(12): 1460-1485. 
De Winter, L., and Baudewyns, P. 2015. 'Candidate centred campaigning in a party centred context: The case of Belgium', Electoral Studies, 39: 295-305.

Eder, N., Jenny, M. and Müller, W. C. 2015. 'Winning over voters or fighting party comrades? Personalized constituency campaigning in Austria', Electoral Studies, 39: 316-328.

Engeli, I. and Lutz, G. 2012. 'When Women Campaign, Do They Win?', paper delivered at the 2nd Conference on the Comparative Candidate Study, Mannheim, Jan. 27-29.

Enyedi, Zs. and G. Tóka. 2007. "The Only Game in Town: Party Politics in Hungary”, in Webb, P. and S. White (eds.), Party Politics in New Democracies, Oxford: OUP.

Enyedi, Zs. 2010. The 2010 Hungarian Candidate Study. Machine readable data files.

Enyedi, Zs. 2011. Politikai képviselet és intézményi alternatívák. Felfogások a polgárok és a politikusok körében. Tardos R., Enyedi Zs. and A. Szabó (eds.): Részvétel, képviselet, politikai változás. Budapest: DKMKA, pp. 243-265.

Evans, J. 2014. 'We know where you live: the importance of local candidates' in Cowley, P., and Ford, R., (eds.), Sex, Lies and the Ballot Box: 50 Things You Need To Know About British Elections. Biteback Publishing.

Ferrara, F., Herron, E.S., Nishikawa, M., 2005. Mixed Electoral Systems. Contamination and Its Consequences. New York: Palgrave Macmillan.

Freeman, P.K., and Richardson, L.E. Jr. 1996. 'Explaining Variation in Casework among State Legislators', Legislative Studies Quarterly, 21(1): 41-56

Hazan, R. Y. 2001. 'The Israeli mixed electoral system: Unexpected reciprocal and cumulative consequences', in Shugart, M. S., and Wattenberg, M. P., Mixed-Member Electoral Systems: The Best of Both Worlds, 351-379. 
Heitshusen, V., Young, G., and D. M. Wood. 2005. 'Electoral Context and MP Constituency Focus in Australia, Canada, Ireland, New Zealand, and the United Kingdom', American Journal of Political Science 49(1): 32-45.

Hennl, A. and T, Zittel. 2011. 'Personalized Election Campaigns and Representation in Mixed Member Systems. Strategies for Electoral Gain or Pandora’s Box?', paper prepared for the ECPR $6^{\text {th }}$ General Conference, Reykjavik.

Ilonszki, G. 2000. "Parties and Parliamentary Party Groups In The Making: Hungary, 19891997”, in Heidar, K. M. and R. A. Koole (eds.) Parliamentary Party Groups in European Democracies: Political Parties Behind Closed Doors, London: Routledge, 214-230.

Ilonszki, G. 2007. 'From Minimal to Subordinate: A Final Verdict? The Hungarian Parliament, 1990-2002', The Journal of Legislative Studies, 13(1): 38-58

Judge, D. and Ilonszki, G. 1995. 'Member-Constituency Linkages in the Hungarian Parliament', Legislative Studies Quarterly, 20(2): 161-176

Lundberg, T. C. 2006. Second-Class Representatives? Mixed-Member Proportional Representation in Britain, Parliamentary Affairs, 59(1): 60-77

King, G., Tomz, M., and Wittenberg, J. 2000. Making the most of statistical analyses: Improving interpretation and presentation. American Journal of Political Science, 44(2): 347-361.

Martin, S. 2011a. 'Parliamentary Questions, the Behaviour of Legislators, and the Function of Legislatures: An Introduction', The Journal of Legislative Studies, 17(3): 259-270.

Martin, S. 2011b. 'Using Parliamentary Questions to Measure Constituency Focus: An Application to the Irish Case', Political Studies, 59: 472-488 
Mayorga, R. A. 2001. 'The mixed-member proportional system and its consequences in Bolivia', in Shugart, M. S., and Wattenberg, M. P., Mixed-Member Electoral Systems: The Best of Both Worlds, 432-446.

Montgomery, K. A. 1999. "Electoral Effects on Party Behavior and Development: Evidence from the Hungarian National Assembly", Party Politics 5(4): 507-523.

Norris, P. 1997. 'The Puzzle of Constituency Service', The Journal of Legislative Studies, 3(2): $29-49$.

Norris, P. 2004. Electoral Engineering. Voting Rules and Political Behaviour. Cambridge: Cambridge University Press

Papp, Z. 2011. “Constituency Focus in the Hungarian MPs' Perceptions of Representation”, DISC Working Paper Series, No. 21

Rich, T. S. 2013. The electoral incentives for legislator perceptions in mixed systems: Integrating evidence from East Asia. Representation, 49(1): 17-31.

Rich, T. S. (2014). Party voting cohesion in mixed member legislative systems: evidence from Korea and Taiwan. Legislative Studies Quarterly,39(1), 113-135.

Russo, F. 2011. 'The Constituency as a Focus of Representation: Studying the Italian Case through the Analysis of Parliamentary Questions', The Journal of Legislative Studies 17(3): 290-301.

Soroka, S., Penner, E. and K. Blidook. (2009) Constituency Influence in Parliament. Canadian Journal of Political Science 42(3): 563-591

Shugart, M. S., Valdini, M. E., and Suominen, K. 2005. 'Looking for Locals: Voter Information Demands and Personal Vote-Earning Attributes of Legislators under Proportional Representation', American Journal of Political Science, 49(2): 437-449. 
Strøm, K. 2000. 'Delegation and Accountability in Parliamentary Democracies', European Journal of Political Research 37(3): 261-289.

Thames, F. C. 2005. A House Divided Party Strength and the Mandate Divide in Hungary, Russia, and Ukraine. Comparative Political Studies, 38(3): 282-303.

Zittel, T. and Gschwend T. 2008. "Individualised Constituency Campaigns in Mixed-Member Electoral Systems: Candidates in the 2005 German Elections”, West European Politics, 31(5): 978-1003.

Wiberg, M. (ed.). 1994. Parliamentary Control in the Nordic Countries: Forms of Questioning and Behavioural Trends. Jyvaskyla: The Finnish Political Science Association. 